\title{
Original
}

\section{Synthesis of Silicon Carbide by High Temperature Flame}

\author{
by \\ Yu Bing $\mathrm{Xu}^{\dagger}$ and Masayoshi SADakata ${ }^{\dagger}$
}

\begin{abstract}
An approach to the synthesis of silicon carbide ( $\mathrm{SiC}$ ) ultrafine (u.f.) particles using silica $\left(\mathrm{SiO}_{2}\right)$ powders by high temperature flame was briefly introduced. Calculations including Gibbs free energy of different reaction systems showed the possibility of $\mathrm{SiC}$ formation. The $\mathrm{SiO}_{2}$ u.f. particles $(5-10 \mathrm{~nm})$ could be formed from the $\mathrm{SiO}_{2}$ powders $(50-100 \mu \mathrm{m})$ by high temperature $\mathrm{CH}_{4-}$ $\mathrm{O}_{2}$ flame around $2500 \mathrm{~K}$. $\beta$-SiC u.f. particles including reticular membrane could be synthesized by an electric furnace at about $2018 \mathrm{~K}$ through $\mathrm{Si}+\mathrm{CH}_{4}$, $\mathrm{SiO}+\mathrm{CH}_{4}$ and $\mathrm{SiO}_{2}+\mathrm{CH}_{4}$ reaction systems, respectively. The effects of $\mathrm{H}_{2}$, $\mathrm{CO}, \mathrm{CO}_{2}$ and $\mathrm{H}_{2} \mathrm{O}$ on the $\mathrm{SiC}$ percentage of synthesized u.f. particles were tested.
\end{abstract}

Key Word : Silicon carbide ; Ultrafine particle ; Flame synthesis

\section{I . Introduction}

One of the important counter measure to $\mathrm{CO}_{2}$ problem is to develop a significant energy saving technology. Ceramic gas turbine or ceramic engine is one of the key technologies in this field. The development of these technologies is mostly dependent on the low energy input and low cost production of non-oxide fine ceramic powders such as $\mathrm{SiC}$ and silicon nitride $\left(\mathrm{Si}_{3} \mathrm{~N}_{4}\right)$ etc.. For these reasons, the studies of $\mathrm{SiC}$ formation process have been intensively carried out by many researchers for a long time. The most representative work among them is $\mathrm{SiC}$ formation by the chemical vapor deposition (CVD) process ${ }^{[1]-[4]}$ which has been presented so far. However, because of using expensive and ignitible $\mathrm{Si}$ source gases such as $\mathrm{SiH}_{4}$ and $\mathrm{CH}_{3} \mathrm{SiCl}_{3}$ etc., the CVD-SiC process is high-cost and not safety.

A low-cost and safe synthesis process of $\mathrm{SiC}$ u.f. particles using $\mathrm{SiO}_{2}$ powders as $\mathrm{Si}$ source and a $\mathrm{CH}_{4}-\mathrm{O}_{2}$ flame around $2500 \mathrm{~K}$ as a high temperature reactor was proposed and its possibility was investigated mainly in our laboratory. The advantages of the flame method are as follows :

1) A cost of $\mathrm{Si}$ source in the synthesis process is exceedingly low, compared with $\mathrm{SiH}_{4}$ and $\mathrm{CH}_{3} \mathrm{SiCl}_{3}$ etc.;

2) This method is a most economical way to realize high temperature field, since it does not require

Received August 31, 1995

† Department of Chemical System Engineering, School of Engineering, The University of Tokyo, 7-3-1 Hongo, Bunkyo-ku,

Tokyo 113, Japan 
an electric power like the plasma ${ }^{[5][6]}$ or laser;

3) A high speed production of u.f. particles by a reaction between $\mathrm{Si}$ vapor and $\mathrm{CH}_{\mathrm{x}}$ radical is carried out under an atmospheric pressure region;

4) It is unnecessary to use expensive refractory materials for the reactor wall, because the high temperature zone can be formed by the flame itself in the space.

The $\mathrm{SiC}$ formation process has two stages. At the primary stage, $\mathrm{SiO}_{2}$ vapor are formed from $\mathrm{SiO}_{2}$ powders in high temperature $\mathrm{CH}_{4}-\mathrm{O}_{2}$ flame. At the secondary stage, $\mathrm{SiC}$ u.f. particles are synthesized by the reaction of $\mathrm{SiO}_{2}$ vapor and $\mathrm{CH}_{4}$. Because the combustion of $\mathrm{CH}_{4}-\mathrm{O}_{2}$ has a complex reaction mechanism which includes more than one hundred elementary reactions and a lot of species such as $\mathrm{CO}, \mathrm{CO}_{2}, \mathrm{H}_{2} \mathrm{O}, \mathrm{OH}, \mathrm{H}, \mathrm{CH}_{3}, \mathrm{CH}_{2}, \mathrm{CH}_{2} \mathrm{O}, \mathrm{CHO}$ etc., ${ }^{[7]}$ the possibilities of $\mathrm{SiC}$ formation by the flame must be investigated fundamentally by using a simple reaction system at first.

In the present study, thermodynamic calculations including $\mathrm{Si} / \mathrm{CH}_{4}, \mathrm{SiO} / \mathrm{CH}_{4}$ and $\mathrm{SiO}_{2} / \mathrm{CH}_{4}$ systems were carried out at first, in order to examine the possibility of $\mathrm{SiC}$ formation from the thermodynamic point of view. Then, as a first experimental step, it was examined whether $\mathrm{SiO}_{2}$ powders could be evaporated into the gas phase and changed to u.f. particles after passing the high temperature $\mathrm{CH}_{4}-\mathrm{O}_{2}$ flame. The experiments of $\mathrm{SiC}$ formation from $\mathrm{Si}+\mathrm{CH}_{4}, \mathrm{SiO}+\mathrm{CH}_{4}$ and $\mathrm{SiO}_{2}+\mathrm{CH}_{4}$ were performed by an electric furnace as the second experiment. Furthermore, the effects of stable species in $\mathrm{CH}_{4}-\mathrm{O}_{2}$ flame such as $\mathrm{H}_{2}, \mathrm{CO}, \mathrm{CO}_{2}$ and $\mathrm{H}_{2} \mathrm{O}$ on the $\mathrm{SiC}$ percentage $(\mathrm{SiC} /(\mathrm{Si}+\mathrm{SiC})$ of synthesized u.f. particles were examined.

\section{Thermodynamic Calculation}

The Gibbs free energy $(\Sigma \Delta \mathrm{G})^{[8]}$ of $\mathrm{Si} / \mathrm{CH}_{4}$ reaction in Eqs. (1), $\Sigma \Delta \mathrm{G}$ of $\mathrm{SiO} / \mathrm{CH}_{4}$ reactions in Eqs. (2), (3) and $\Sigma \Delta \mathrm{G}$ of $\mathrm{SiO}_{2} / \mathrm{CH}_{4}$ reactions in Eqs. (4), (5), (6) under the various reaction temperature were calculated respectively.

$$
\begin{aligned}
& \mathrm{Si}(\mathrm{g})+\mathrm{CH}_{4}(\mathrm{~g}) \rightarrow \mathrm{SiC}(\mathrm{s})+2 \mathrm{H}_{2}(\mathrm{~g}) \\
& \mathrm{SiO}(\mathrm{g})+\mathrm{CH}_{4}(\mathrm{~g}) \rightarrow \mathrm{SiC}(\mathrm{s})+\mathrm{H}_{2} \mathrm{O}(\mathrm{g})+\mathrm{H}_{2}(\mathrm{~g}) \\
& \mathrm{SiO}(\mathrm{g})+2 \mathrm{CH}_{4}(\mathrm{~g}) \rightarrow \mathrm{SiC}(\mathrm{s})+\mathrm{C}(\mathrm{s})+\mathrm{H}_{2} \mathrm{O}(\mathrm{g})+3 \mathrm{H}_{2}(\mathrm{~g}) \\
& \mathrm{SiO}_{2}(\mathrm{~g})+\mathrm{CH}_{4}(\mathrm{~g}) \rightarrow \mathrm{SiC}(\mathrm{s})+2 \mathrm{H}_{2} \mathrm{O}(\mathrm{g}) \\
& \mathrm{SiO}_{2}(\mathrm{~g})+2 \mathrm{CH}_{4}(\mathrm{~g}) \rightarrow \mathrm{SiC}(\mathrm{s})+\mathrm{CO}_{2}(\mathrm{~g})+4 \mathrm{H}_{2}(\mathrm{~g}) \\
& \mathrm{SiO}_{2}(\mathrm{~g})+3 \mathrm{CH}_{4}(\mathrm{~g}) \rightarrow \mathrm{SiC}(\mathrm{s})+2 \mathrm{CO}(\mathrm{g})+6 \mathrm{H}_{2}(\mathrm{~g})
\end{aligned}
$$

Fig. 1 shows that $\Sigma \Delta \mathrm{G}$ versus temperature plot for these reactions. All of them tend to negative with an increase of temperature. $\Sigma \Delta \mathrm{G}$ of $\mathrm{SiO} / \mathrm{CH}_{4}$ reactions or $\mathrm{SiO}_{2} / \mathrm{CH}_{4}$ reactions also tend to negative with an increase of $\mathrm{CH}_{4}$ molecular.

$\mathrm{SiO}_{2}$ equilibrium vapor pressures was calculated by Kelley's experience equation ${ }^{[9]}$ where the size effect was estimated by Kelvin's equation. Fig. 2 shows that $\mathrm{SiO}_{2}$ equilibrium vapor pressure is about $0.15-0.18 \mathrm{~atm}$ at around $2000 \mathrm{~K}$. Through these calculations, it is known that $\mathrm{SiO}_{2}$ powders can be vaporized in the temperature condition of up to $2000 \mathrm{~K}$. Hence, it is expected that the gas phase synthetic reactions of $\mathrm{Si} / \mathrm{CH}_{4}, \mathrm{SiO} / \mathrm{CH}_{4}$ or $\mathrm{SiO}_{2} / \mathrm{CH}_{4}$ can proceed over a $2000 \mathrm{~K}$ temperature condition. 


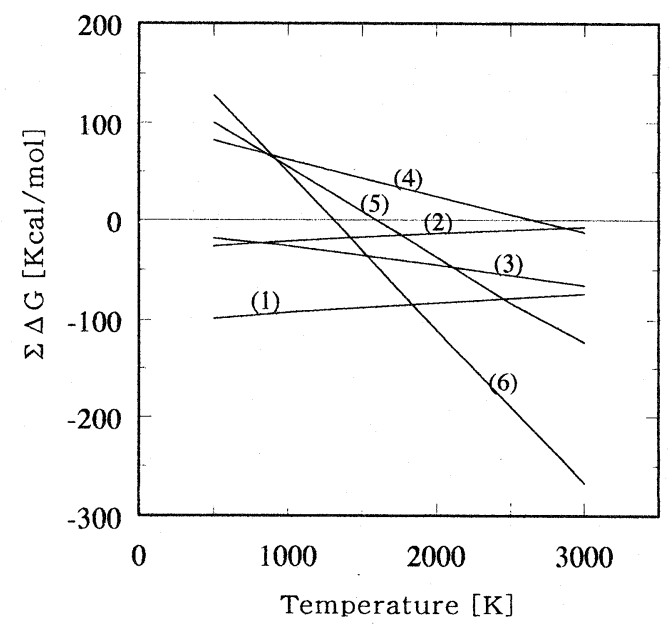

Figure 1. $\quad \Sigma \Delta \mathrm{G}$ versus temperature plot for $\mathrm{SiC}$ formation reaction : (1), (2), (3), (4), (5) and (6).

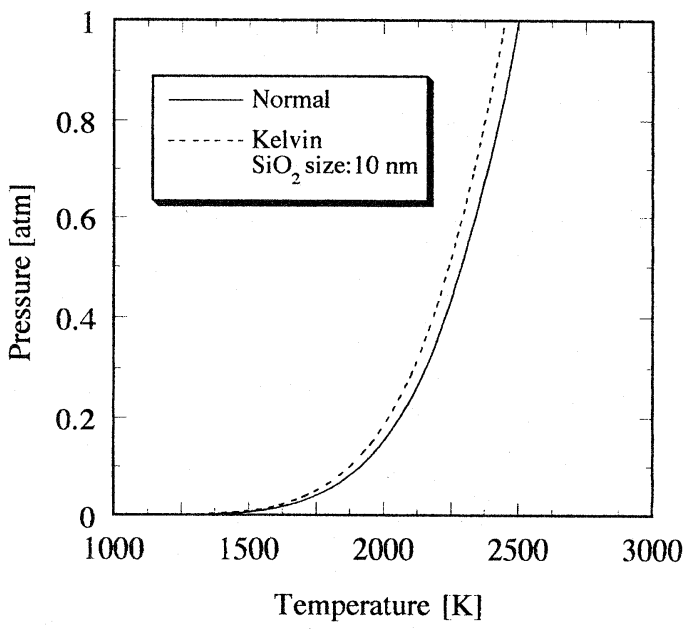

Figure 2. $\mathrm{SiO}_{2}$ vapor pressure versus temperature.

\section{Experimental Procedure}

A flame reactor shown in Figure 3 was used for the evaporation of $\mathrm{SiO}_{2}$ powders. It consisted of three parts those were a flame gas feed, a source powder supply and a reactor in an electric furnace. Gas flows including $\mathrm{CH}_{4}, \mathrm{O}_{2}$ and Ar carrier gas were controlled by mass flow controllers. $\mathrm{SiO}_{2}$ powders were fed into the reactor through a fluidized bed using 75 vol.\% $\mathrm{O}_{2}$ diluted by argon (Ar) as a carrier gas. The size range of supplied $\mathrm{SiO}_{2}$ powders was $50-100 \mu \mathrm{m}$. The outside of the reactor tube was heated by an electric furnace of silicon-knit heaters (Model : DSp-24, Siliconit Heater Industry Corp.). The temperature in the middle part of reactor tube was $1600 \mathrm{~K}$. There 


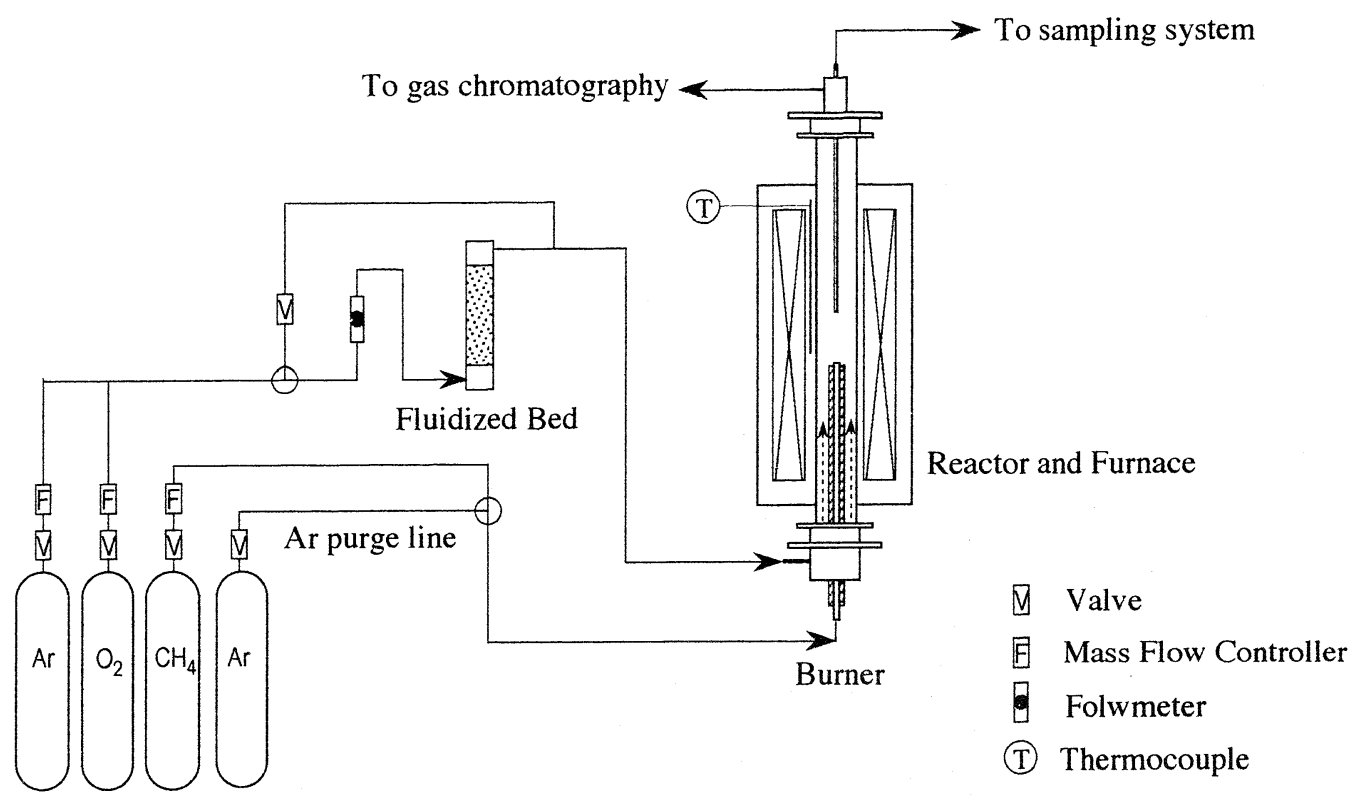

Figure 3. Schematic of the experimental apparatus of a flame reactor.

were four nozzles in the top of burner whose diameter was $0.88 \mathrm{~mm}$ and the gas linear velocity was $83 \mathrm{~m} / \mathrm{s}$ which corresponds to Reynolds number of 3900 . The equivalence ratio was $0.8-1.4$, and the temperature of $\mathrm{CH}_{4}-\mathrm{O}_{2}$ flame was around $2500 \mathrm{~K}$. The formed particles were collected through a sample probe in a screen filter and were examined by TEM (Model : H-7000, Hitachi Co., Ltd.), XRD (Model : RAD-C, Rigaku Co., Ltd.) with Ni-filtered $\mathrm{CuK}_{a}$ and FT-IR (Model : FTIR-8600PC, SHIMADZU Corp.).

The possibilities for the synthesis of $\mathrm{SiC}$ using $\mathrm{SiO}_{2}$ powders as $\mathrm{Si}$ source was investigated by an electric funace system shown in Figure 4a. It consisted of an electric resistance furnace equipped by $\mathrm{LaCrO}_{3}$ heaters (Nippon Kagaku Togyo Co., Ltd.) and a control unit (Okura Electronic Corp.). A maximum temperature capability of heaters was $2073 \mathrm{~K}$ and about $2018 \mathrm{~K}$ at the inside of the alumina reactor tube (ID : $30 \mathrm{~mm}$ ). A heating rate was $4.0 \mathrm{~K} / \mathrm{min}$ which was measured by a $\mathrm{Pt40Rh} 20$ thermocouple between the heaters and the reactor tube. An alumina crucible loading $\mathrm{Si}$ source powders (Av. size : $10 \mathrm{~nm}$, Mizusawa Chemical Industry Corp.) was kept in the hot zone of the furnace. The $\mathrm{CH}_{4}$ (Conc.: 0.5-3.0 vol.\%) balanced by Ar was introduced into the top of the reactor tube and exhausted from the bottom. After the completion of the synthesis experiments, the specimens were collected from the crucible.

Furthermore, we prepared another method of collecting specimen shown in Figure $4 \mathrm{~b}$ to collect the synthesized $\mathrm{SiC}$ u.f. particles from $\mathrm{Si}, \mathrm{SiO}$ and $\mathrm{SiO}_{2}$ powders (size range : 1-3 $\mu \mathrm{m}$ ) as $\mathrm{Si}$ source. The $\mathrm{CH}_{4}$ balanced by Ar was introduced into the bottom of the reactor tube and exhausted from the top. To prevent any possibility for oxidation of $\mathrm{Si}$ source or $\mathrm{SiC}$ by impurity oxygen during reaction, another Ar gas as a purge gas was fed along the wall of the reactor tube which ensured the 


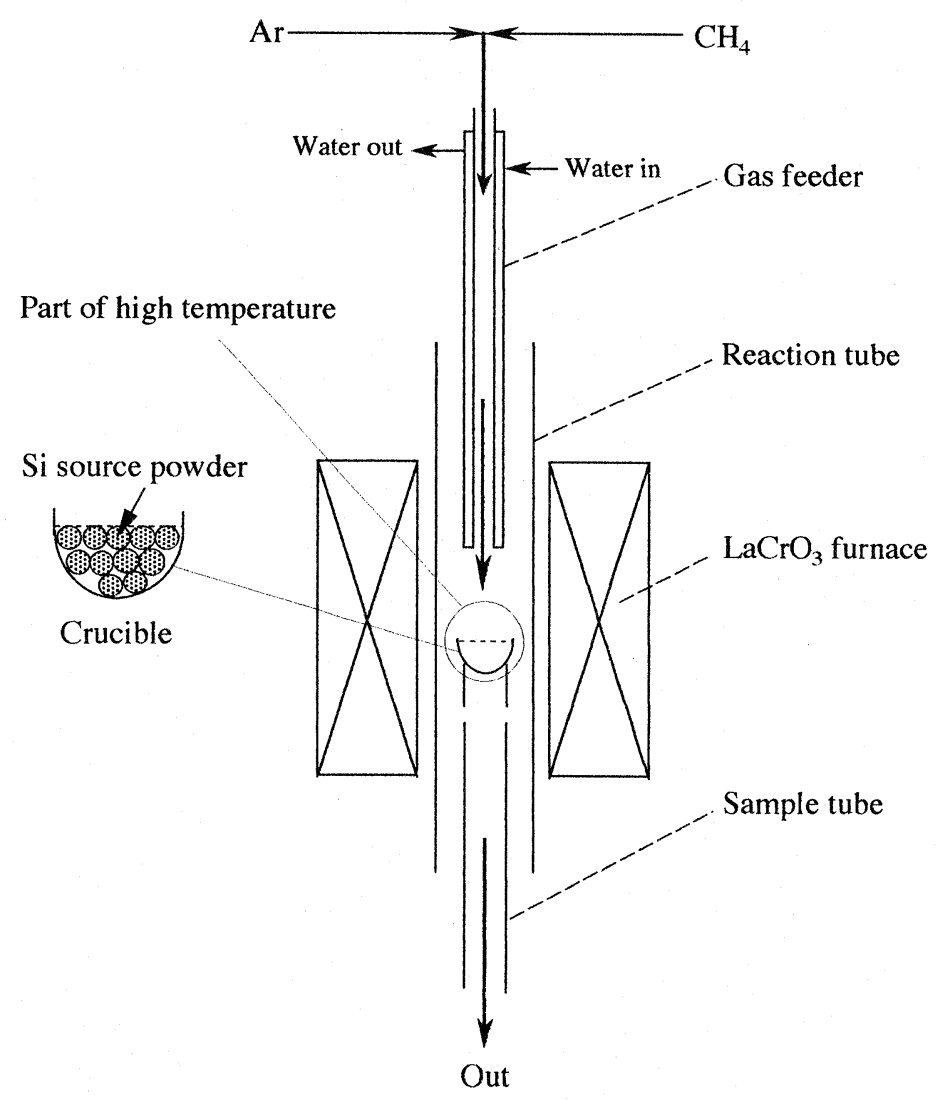

(a) Type 1 .

Figure 4. Schematic of the experimental apparatus: (a) type 1 and (b) type 2 of an electric furnace.

inside pressure about $20-40 \mathrm{~mm} \mathrm{H}_{2} \mathrm{O}$ higher than an atmospheric pressure in the whole experimental process. A paper filter was directly put above the reactor tube to trap solid u.f. particles.

$\mathrm{H}_{2}$ (Conc: 10.0 vol.\%), $\mathrm{CO}$ (Conc.: 2.0 vol.\%), $\mathrm{CO}_{2}$ (Conc.: 10.0 vol.\%) or $\mathrm{H}_{2} \mathrm{O}$ (Conc.: 1.0 vol.\%) diluted by Ar carrier gas were respectively fed into the hot zone of the reactor tube. The gas flow velocity was about $14.0 \mathrm{~cm} / \mathrm{s}$ at $2018 \mathrm{~K}$. All of the collected specimens were examined

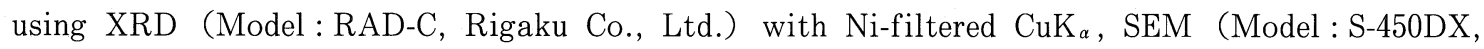
Hitachi Co. Ltd.) and TGA (Model : TGD-7000RH, Vacuum Science and Engineering Corp.).

\section{Results and Discussion}

\section{(1) Evaporation Experiment}

The evaporation of $\mathrm{SiO}_{2}$ powders in the $\mathrm{CH}_{4}-\mathrm{O}_{2}$ flame was conducted under the oxidizing condition. The experimental conditions were $\mathrm{CH}_{4}: 10 \mathrm{l} / \mathrm{min}, \mathrm{O}_{2}: 25 \mathrm{l} / \mathrm{min}$, Ar : $5 \mathrm{l} / \mathrm{min}$; feed time :2 min. The white fine particles were collected from the filter. Figure 5 shows a TEM photograph of 


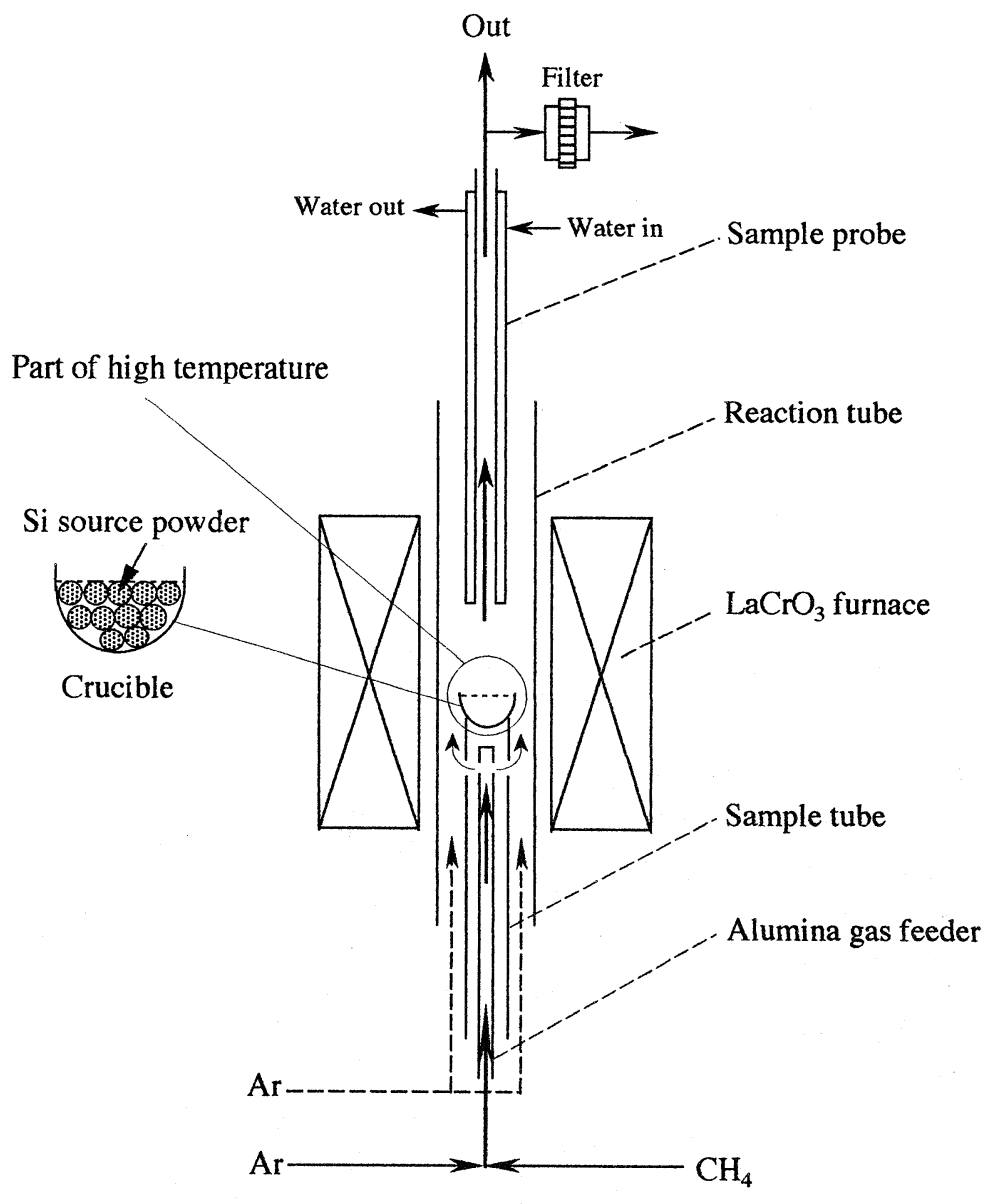

(b) Type 2.

Figure 4. Schematic of the experimental apparatus: (a) type 1 and (b) type 2 of an electric furnace.

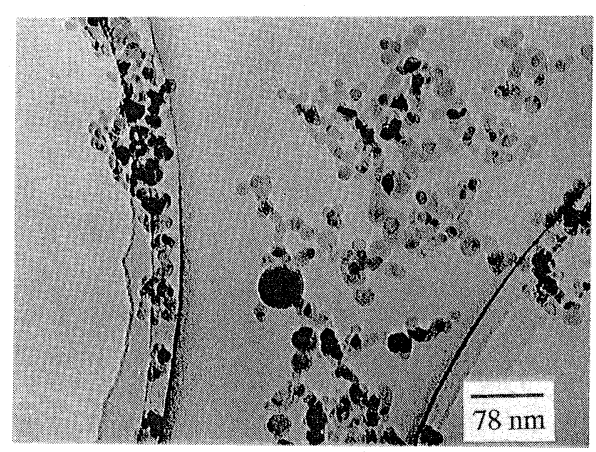

Figure 5. TEM photograph of u.f. particles formed from the evaporation of $\mathrm{SiO}_{2}$ powders in a flame reactor. 
them. The particle sizes observed by TEM were basically in the range 5-10 nm, confirming the evaporation and condensation mechanism of the supplied $\mathrm{SiO}_{2}$ powders. The relative and accumulative distribution were determined by counting several hundreds particles from the TEM photographs. $\mathrm{XRD}$ of the particles shows only the peaks of $\mathrm{SiO}_{2}$ (JCPDS N0.27-605 ${ }^{[00]}$ ). It shows that $\mathrm{SiO}_{2}$ powders could be evaporated into the gas phase through the high temperature $\mathrm{CH}_{4}-\mathrm{O}_{2}$ flame.

(2) Synthesis of SiC Reticular Membrane

The $\mathrm{SiC}$ synthesis experiment was performed through the reaction of $\mathrm{SiO}_{2}+\mathrm{CH}_{4}$. The murky grey membrane was collected from the alumina crucible wall. Figure 6 shows a SEM photograph and XRD patterns of the specimen. From the SEM photograph, it is noted that only reticular membrane specimen was observed but u.f. particles were not observed. From the XRD result, $\beta-\mathrm{SiC}$ (JCPDS N0.29- 1129 ${ }^{[10]}$ ) and $\mathrm{SiO}_{2}$ (JCPDS N0.27-605) patterns were observed mainly. It was clear that the $\beta$-SiC reticulation was successfully synthesized in the experiment system of Figure 4a. The percentage of $\mathrm{SiC}$ u.f. particles $(\mathrm{SiC} /(\mathrm{Si}+\mathrm{SiC}))$, which was determined from the calibration curves of the relative intensities, using the XRD patterns of the SiC-Si standard mixtures and TGA results, was about $66 \%$. In addition, when the electric furnace was cooled down after $\mathrm{CH}_{4}$ feed was

(a)
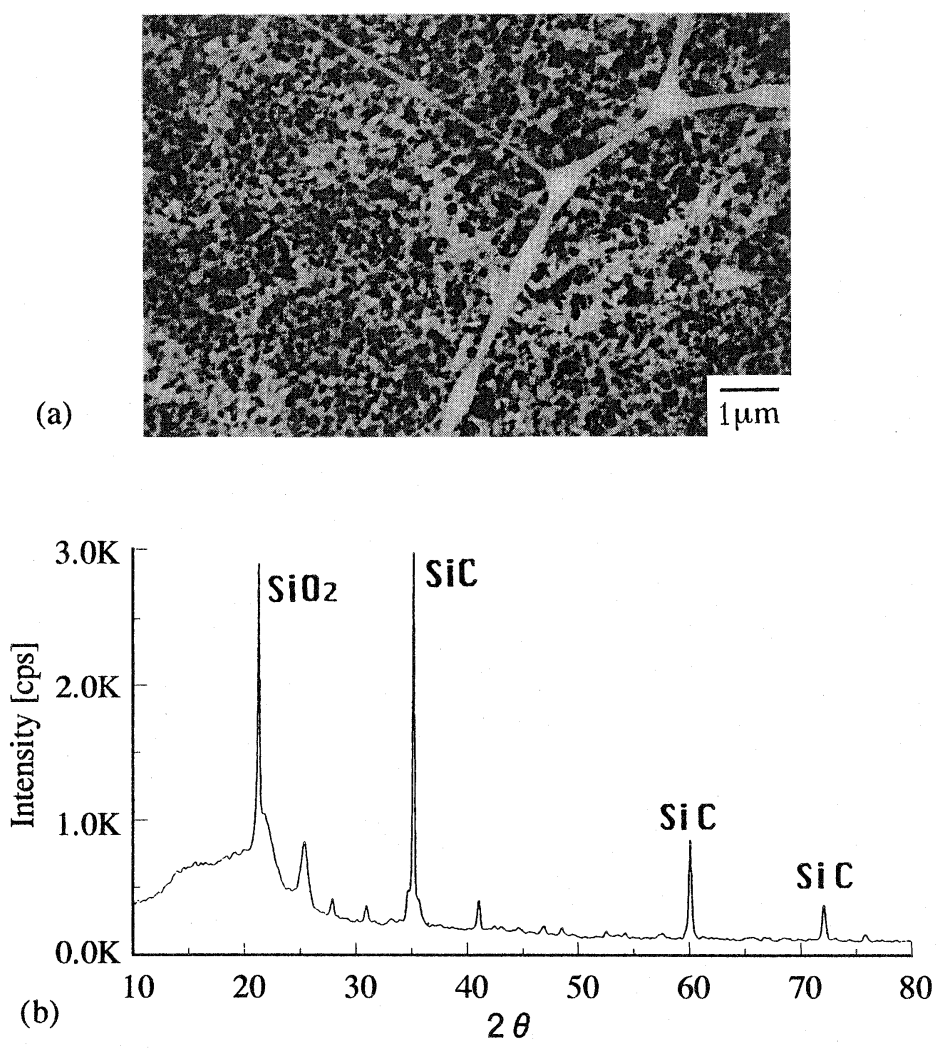

Figure 6. (a) SEM photograph and (b) XRD pattern of synthetic $\mathrm{SiC}$ using experimental system type 1 . 


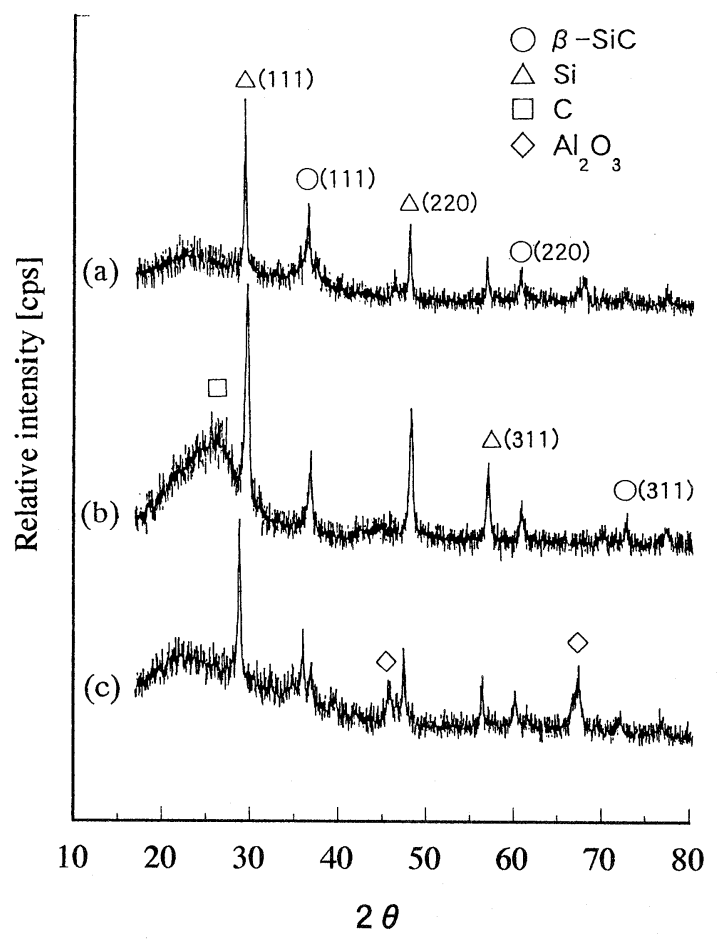

Figure 7. XRD patterns of products for the reaction systems of (a) $\mathrm{Si}+\mathrm{CH}_{4}$, (b) $\mathrm{SiO}+\mathrm{CH}_{4}$ and (C) $\mathrm{SiO}_{2}+\mathrm{CH}_{4}$ in an electric furnace.

stopped, surplus $\mathrm{SiO}_{2}$ continues to evaporate and deposited on the synthetic $\mathrm{SiC}$ adhere in the alumina crucible wall. This is the reason why $\mathrm{SiO}_{2}$ crystal was examined by XRD.

(3) Synthesis of SiC Ultrafine Particles

The synthesis experiments of $\mathrm{SiC}$ u.f. particles were performed through the reactions of $\mathrm{Si}+\mathrm{C}$ $\mathrm{H}_{4}, \mathrm{SiO}+\mathrm{CH}_{4}$ and $\mathrm{SiO}_{2}+\mathrm{CH}_{4}$, respectively. Figure 7 shows XRD patterns of the specimen collected from the paper filters. The XRD results of specimens show the peaks for $\beta$-SiC (JCPDS N0.29-1129) and $\mathrm{Si}$ (JCPDS N0.27-1402 ${ }^{[10]}$ ). The scales of $\beta$-SiC crystallites calculated by Scherrer's equation were $18.3 \mathrm{~nm}, 27.4 \mathrm{~nm}$ and $28.9 \mathrm{~nm}$ for $\mathrm{Si}, \mathrm{SiO}$ and $\mathrm{SiO}_{2}$ source powders, respectively. It was clear that the $\beta$-SiC u.f. particles (size range : 18-29 nm) were successfully synthesized in the experimental system of Figure $4 \mathrm{~b}$. The percentages of $\mathrm{SiC}$ were $72 \%, 54 \%, 78 \%$ (shown in Figure 9) for $\mathrm{Si}, \mathrm{SiO}$ and $\mathrm{SiO}_{2}$ source powders, respectively. In addition, XRD peak of carbon (C) which might be formed from $\mathrm{CH}_{4}$ decomposition and alumina $\left(\mathrm{Al}_{2} \mathrm{O}_{3}\right)$ formed from a small impurity in $\mathrm{SiO}_{2}$ powders were observed.

(4) Effect of $\mathrm{H}_{2}, \mathrm{CO}, \mathrm{CO}_{2}$ or $\mathrm{H}_{2} \mathrm{O}$

The effects of $\mathrm{H}_{2} \mathrm{CO}, \mathrm{CO}_{2}$ and $\mathrm{H}_{2} \mathrm{O}$ on the $\mathrm{SiC}$ percentage of synthesized u.f. particles were performed through the reactions of $\mathrm{Si}+\mathrm{CH}_{4}+\mathrm{H}_{2}, \mathrm{Si}+\mathrm{CH}_{4}+\mathrm{CO}, \mathrm{Si}+\mathrm{CH}_{4}+\mathrm{CO}_{2}$ and $\mathrm{Si}+\mathrm{CH}_{4}+$ $\mathrm{H}_{2} \mathrm{O} ; \mathrm{SiO}+\mathrm{CH}_{4}+\mathrm{H}_{2}, \mathrm{SiO}+\mathrm{CH}_{4}+\mathrm{CO}, \mathrm{SiO}+\mathrm{CH}_{4}+\mathrm{CO}_{2}$ and $\mathrm{SiO}+\mathrm{CH}_{4}+\mathrm{H}_{2} \mathrm{O} ; \mathrm{SiO}_{2}+\mathrm{CH}_{4}+\mathrm{H}_{2}$, 


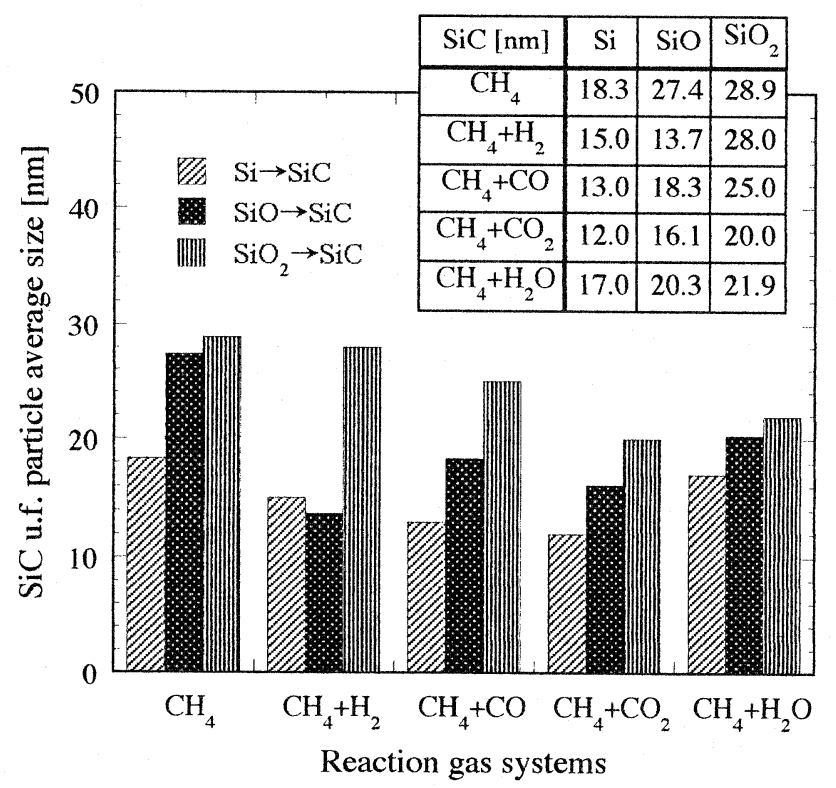

Figure 8. Change of $\mathrm{SiC}$ u.f. particle average size under different reaction systems.

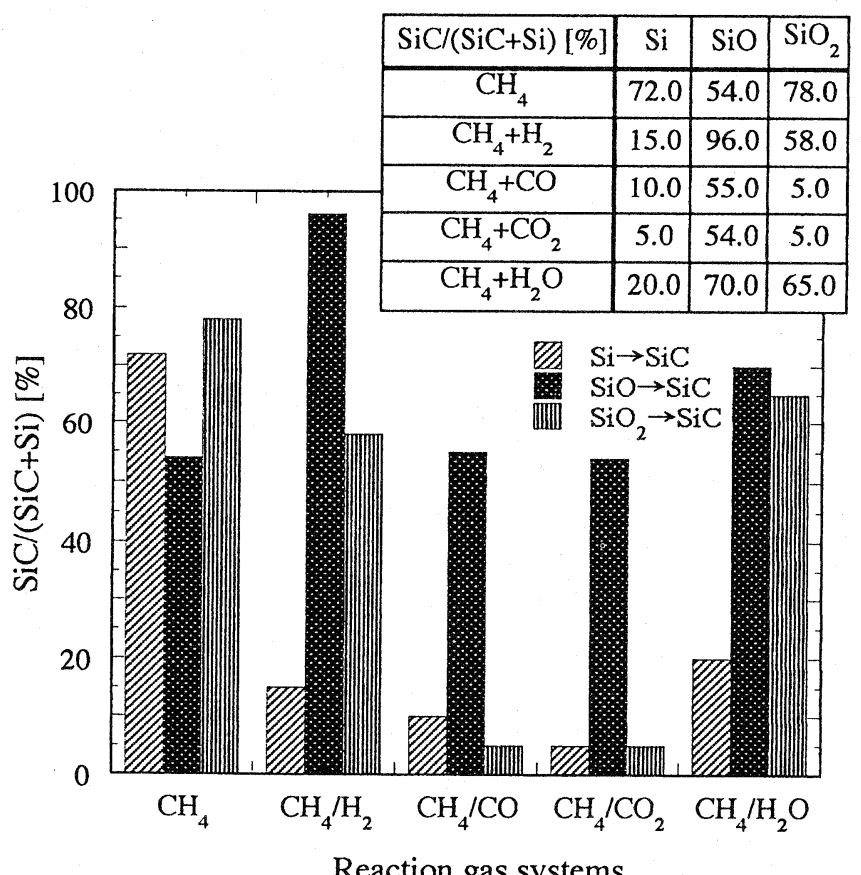

Figure 9. SiC percentage of synthesized u.f. particles under different reaction systems. 
$\mathrm{SiO}_{2}+\mathrm{CH}_{4}+\mathrm{CO}, \mathrm{SiO}_{2}+\mathrm{CH}_{4}+\mathrm{CO}_{2}$ and $\mathrm{SiO}_{2}+\mathrm{CH}_{4}+\mathrm{H}_{2} \mathrm{O}$, respectively. All of the XRD results of specimens showed the peaks for $\beta$-SiC (JCPDS N0.29-1129) and Si (JCPDS N0.27-1402). The scale range of $\beta$-SiC crystallites calculated by Scherrer equation was 10-30 nm shown in Figure 8 . They showed that the $\beta$-SiC u.f. particles were successfully synthesized even if $\mathrm{H}_{2}, \mathrm{CO}, \mathrm{CO}_{2}$ or $\mathrm{H}_{2} \mathrm{O}$ were added to the reaction systems.

Figure 9 shows the $\mathrm{SiC}$ percentage changes of synthesized u.f. particles with different reaction systems. It is noteworthy that the effects of $\mathrm{CO}, \mathrm{CO}_{2}$ or $\mathrm{H}_{2} \mathrm{O}$ on $\mathrm{Si}+\mathrm{CH}_{4}$ and $\mathrm{SiO}_{2}+\mathrm{CH}_{4}$ reaction systems are bigger than those on $\mathrm{SiO}+\mathrm{CH}_{4}$. For example, the addition of $\mathrm{CO}$ or $\mathrm{CO}_{2}$ decreased the synthesized $\mathrm{SiC}$ percentages of $\mathrm{Si}+\mathrm{CH}_{4}$ and $\mathrm{SiO}_{2}+\mathrm{CH}_{4}$ reaction systems from $72 \%$ and $78 \%$ down to $10 \%$ and $5 \%$ respectively, while those of $\mathrm{SiO}+\mathrm{CH}_{4}$ reaction system was not changed. It is also noteworthy that the percentage of $\mathrm{SiC}$ which was $54 \%$ in $\mathrm{SiO}+\mathrm{CH}_{4}$ reaction system is increased to $96 \%$ by adding $\mathrm{H}_{2}$.

\section{Conclusions}

The possibilities for the formation of $\mathrm{SiC}$ u.f. particles from $\mathrm{SiO}_{2}$ powders were examined experimentally.

$\mathrm{SiO}_{2}$ powders were evaporated into the gas phase after passing through the high temperature $\mathrm{C}$ $\mathrm{H}_{4}-\mathrm{O}_{2}$ flame at around $2500 \mathrm{~K}$. The $\beta$-SiC u.f. particles including reticular membrane were successfully synthesized in three reaction systems including $\mathrm{Si}+\mathrm{CH}_{4}, \mathrm{SiO}+\mathrm{CH}_{4}$ and $\mathrm{SiO}_{2}+\mathrm{CH}_{4}$ by an electric furnace at about $2018 \mathrm{~K}$. Furthermore, the effects of $\mathrm{H}_{2}, \mathrm{CO}, \mathrm{CO}_{2}$ and $\mathrm{H}_{2} \mathrm{O}$ on the $\mathrm{SiC}$ percentage of synthesized u.f. particles were examined.

\section{Acknowledgment}

The authors would like to thank Mr. Akihito Matsumoto of Hitachi Cooperation Limited for providing the supports on the evaporation experiments.

\section{References}

1) J. Schlichting, Review 13, "Chemical Vapor Deposition of Silicon Carbide," Powder Metall. Int., 12 [3] 141-147 (1980), continued 12 [4] 196-200 (1980).

2) Alan W. Weimer, Kevin J. Nilsen, Gene A. Cochran, and Raymond P. Roach, "Kinetics of Carbothermal Reduction Synthesis of Beta Silicon Carbide," AIChE Journal, 39 [3] 493-503 (1993).

3) J. M. Harris, H. C. Gatos, and A. F. Witt, "Growth Characteristics of Alpha-Silicon Carbide: I, Chemical Vapor Deposition," J. Electrochem. Soc., 118 [2] 335-38 (1971).

4) W. F. Knippenberg, G. Verspui, and A. W. C. von Kemenade, "Growth Mechanisms of Silicon Carbide in Vapour Deposition," Silicon Cabide, Proc. lnt. Conf., 3rd, 1973, 92-107.

5) P. Kong, T. T. Huang, and E.Pfender, "Synthesis of Utrafine Silicon Carbide Powders in Thermal Arc Plasmas," IEEE Trans. Plasma Sci., PS-14 [4] 357-69 (1986).

6) J. Y. Guo, F. Gitzhofer, M. I. Boulos, "Induction plasma synthesis of ultrafine SiC powders from silicon and $\mathrm{CH}_{4}, "$ J. Moter. Sci., 30, 5589-99 (1995).

7) J. M. Beer and N. A. Chigier, "Combustion Aerodynamics," pp. 196-209 in Modelling of Combustion Systems. Edited by J. M. Beer. Applied Scicence Publishers Ltd, 1972.

8) JANAF Thermochemical Tables, 2nd ed., Natl. Stand. Ref. Dota. Ser. ( U. S. Natl. Bur. Scand.), 
No. 37 (1971).

9) H. F. Ferguson and D. M. Wilkins "Some Data Relevant to the Volatilisation of Ash Components from Slags at High Temperatures," The British Coal Utilisation Reseorch Association, Vol.XXVII, No. 10, 462-73, Oct. 1963.

10) International Centre for Diffraction Data, "Alphabetical Index Inorganic Phases," 708-709, Powder Diffraction File, 1985. 